\title{
Magnitude and Associated Factors of Institutional Delivery Among Reproductive Age Women in Southwest Ethiopia
}

This article was published in the following Dove Press journal: International Journal of Women's Health

\section{Tewodros Yosef $(\mathbb{D}$}

Department of Public Health, College of Medicine and Health Sciences, Mizan-Tepi University, Mizan Teferi, Ethiopia
Correspondence: Tewodros Yosef Department of Public Health, College of Medicine and Health Sciences, Mizan-Tepi University, P.o. Box: 260, Mizan Teferi, Ethiopia

Email tewodrosyosef47@mtu.edu.et
Background: Despite the global maternal mortality ratio (MMR) fallen by nearly $44 \%$ from 1990 to 2015, however, maternal mortality remains a global problem. Reducing maternal morbidity and mortality is a global priority, which is particularly relevant for developing countries like Ethiopia. A good strategy for reducing maternal morbidity and mortality is increasing institutional delivery service utilization. This study aimed to assess the magnitude and associated factors of institutional delivery among reproductive-age women in southwest Ethiopia.

Methods: A community-based cross-sectional study was conducted among 526 women at Mizan-Aman town from January 1 to 30, 2019. The data were collected through face-to-face interviews, and a structured questionnaire was used to assess the prevalence and associated factors of institutional delivery among reproductive-age women who delivered in the past one year. The collected data were entered into the Epi Data manager and analyzed using SPSS version 21. Binary logistic regression was done to determine the association between dependent and expected independent variables. Statistical significance was declared at $\mathrm{p}<$ 0.05 in the multivariable logistic regression analysis.

Results: Of the 526 mothers interviewed, the proportion of institutional delivery was $76 \%$, 95\% CI (72.4\%-79.7\%). The study also found maternal age $25-34$ years (AOR $=1.89,95 \%$ $\mathrm{CI}[1.42-3.26])$ and 35 years and above $(\mathrm{AOR}=3.51,95 \% \mathrm{CI}[1.52-7.85])$, monthly income $\geq 36$ USD $(\mathrm{AOR}=2.22,95 \%$ CI [1.12-4.13]), being multiparity $(\mathrm{AOR}=1.98,95 \%$ CI [1.08-3.62]), having $\mathrm{ANC}$ visit (AOR=10.5, 95\% CI [6.76-28.3]), knowledge of pregnancy danger signs $(\mathrm{AOR}=5.51,95 \% \mathrm{CI}[3.46-10.2])$ and experience of pregnancy danger signs ( $\mathrm{AOR}=3.86,95 \% \mathrm{CI}$ [2.67-7.29]) were significantly associated with institutional delivery.

Conclusion: The utilization of institutional delivery service among mothers in the study area was good. But, more effort is needed to increase service utilization to $100 \%$. The provision of the continuous house to house health education regarding institutional delivery is an important segment of intervention that can be done through health extension workers. Besides, counseling mothers on the importance of institutional delivery by health professionals at each ANC follow-up visit plays paramount importance.

Keywords: institutional delivery, factors, reproductive age women, Mizan-Aman, southwest Ethiopia

\section{Introduction}

Pregnancy and childbirth are important periods in women's life. However, millions of women living in developing countries die of complications related to childbirth. ${ }^{1,2}$ Despite the global maternal mortality ratio (MMR) fallen by nearly $44 \%$ from an estimated 385 maternal deaths per 100000 live births in 1990 to an MMR of 216 in 
2015. ${ }^{3}$ Maternal mortality remains a global problem with nearly all (99\%) of maternal death occur in the developing countries and $56 \%$ of the burden accounted for sub-Saharan countries. ${ }^{4,5}$ Ethiopia is still with highest MMR in the world and is one of 10 countries that contributed $60 \%$ of the global maternal death burden in $2010^{6}$ with an estimated 420/ 100,000 live births, which is far from the World Health Organization (WHO) target $(267 / 100,000)$ for $2015 .^{7}$

Reducing maternal morbidity and mortality is a global priority, which is particularly relevant for developing countries like Ethiopia. ${ }^{8}$ Early diagnosis of pregnancy, professional follow-up, and skilled delivery service are the main interventions that reduce maternal morbidity and mortality. ${ }^{9}$ Several studies revealed that increasing institutional delivery is a good strategy for reducing maternal morbidity and mortality. ${ }^{8,10-13}$

The factors associated with institutional delivery are multiple and include age, income status, education, occupation, religion, residence, attending $\mathrm{ANC}$, frequency of ANC visit, age at first marriage, age at first pregnancy, types of pregnancy (planned/unplanned), gravidity, parity, owing radio and/or television, knowledge, and occurrence of pregnancy danger signs. ${ }^{1,2,5,8,9,14-23}$

Ethiopia is one of the six countries that contribute to more than $50 \%$ of global maternal deaths. ${ }^{24}$ Despite it is known that delivery attended by a skilled provider at a health facility reduced maternal deaths, but more than half of all births in Ethiopia take place at home. ${ }^{25}$ The proportion of births attended by skilled attendants in Ethiopia is very much lower than that of countries in SSA. Even for women who have access to the services, the proportion of births occurring at health facilities is very low. ${ }^{8,26}$

According to EDHS 2011 report, nine women in every ten deliver at home in Ethiopia. The situation is much worse in the southern region. To control the burden of high maternal death in Ethiopia, the low institutional delivery service coverage has to be improved..$^{25}$ Any intervention aimed at improving the institutional delivery service use can only be possible when there is sufficient data on the issue. Therefore, this study aimed to assess the magnitude and associated factors of institutional delivery among reproductive-age women in southwest Ethiopia.

\section{Methods}

\section{Study Design, Area, and Period}

A community-based cross-sectional study was conducted in Mizan-Aman town, Bench-Sheko zone, southwest Ethiopia from January 1 to 30, 2019. Mizan-Aman town is the administrative center of the Bench-Sheko zone and has two subcity (namely Mizan \& Aman) and five kebeles (smallest administrative unit in Ethiopia), three Kebeles are under Mizan sub-city and two kebeles are under Aman sub-city. The total population of the town was 52,210 (18,625 male and $33,585 f$ emale). However, the literacy rate is not known.

\section{Populations}

The source population was all women in the reproductive age group (15-49 age years old) who gave birth within the past 12 months and who had been living at least for six months in Mizan-Aman town. The study population was randomly selected women of reproductive age group.

\section{Sample Size Determination}

The required sample size for this study was calculated using a single population proportion formula. Using the proportion of institutional delivery was $31 \%$, which was taken from a previous study done at cheha district, Ethiopia $^{25}$ with $95 \%$ confidence level, 5\% margin of error, 1.5 design effects, and $10 \%$ of non-response rate compensation. The final computed sample size was 542 .

\section{Sampling Procedure}

Stratification of the town was done into urban $(n=3)$ and semi-urban $(\mathrm{n}=2)$ kebeles. Then, in each stratum, 1/3 of kebeles (1 urban and 1 semi-urban) kebeles were selected by a simple random sampling method. Census was done in the selected two kebeles to identify mothers who gave birth in the last 1 year before the data collection. Then, the total sample size $(n=537)$ was allocated proportionally (271 and 266 mothers from urban and semi-urban kebeles respectively) on each kebele based on the number of eligible mothers present in the area. Then the total households in each kebeles were divided by the total sample sizes allocated to get the sampling intervals $(\mathrm{k})$. The random start was selected randomly (by lottery method) and finally, every sampling interval (k) from a random start was studied until the required sample size was obtained.

\section{Study Variables}

The dependent variable was institutional delivery. The independent variables were socio-demographic factors (maternal age, women's occupation, women's education, husband education, and income), obstetric factors (gravidity, parity, and experience of danger signs), health service- 
related factors (ANC follow up, and frequency of ANC) and knowledge of obstetric danger signs.

\section{Operational Definitions}

Institutional delivery use was defined as mothers who used institutions (governmental hospitals, or health centers, and/or private hospitals or clinics) for delivery in their last pregnancy.

Prevalence was defined as the frequency of study subjects who had a history of institutional delivery in their last delivery.

Knowledgeable about pregnancy danger signs refers to those participants who mentioned at least three pregnancy danger signs spontaneously, otherwise not knowledgeable. ${ }^{27}$ History of pregnancy danger sign(s) refers to any sign of pregnancy danger sign(s) reported by women which may occur in women during pregnancy.

\section{Data Collection Tools \& Techniques}

Data were collected through face-to-face interviews using a structured questionnaire. The questionnaire was prepared by reviewing related previous literature. The knowledge of pregnancy danger signs was assessed by asking key pregnancy danger signs. ${ }^{28}$ They are asked "Did you know pregnancy danger signs?" If yes, mention? Those who mentioned at least three pregnancy danger signs spontaneously considered as knowledgeable, otherwise not knowledgeable. The questionnaire was first translated from English to the local language (Amharic) and back to English. A pretest was done on 5\% of the total sample size in Tepi town and a necessary adjustment was made. The training was given for data collectors and supervisors regarding the objective and method of data collection and discusses the presence of unclear questions in the questionnaire.

\section{Plan for Data Analysis}

Data were checked for completeness and consistency and then coded and entered into Epi Data manager software and analyzed using SPSS version 21. Binary logistic regression was done to determine the association between dependent and expected independent variables. Independent variables significantly associated with the dependent variable at a p-value of less than or equals to 0.25 in the bivariate logistic regression model were fitted into the multivariable logistic regression model to control the effect of confounding. Statistical significance was declared at $\mathrm{p}<0.05$ in the multivariable logistic regression analysis. Multi-collinearity between independent variables in the model was checked, and the variance inflation factor (VIF) was found acceptable (less than 2). The HosmerLemeshow goodness-of-fit test indicated $(\mathrm{P}=0.712)$ that the model was good enough to fit the data well.

\section{Results}

\section{Socio-Demographic Factors}

Of the 542 mothers recruited, 526 were completed the interview, yielding a response rate of $97.1 \%$. The mean age of respondents was $28.8( \pm 5.5 \mathrm{SD})$ years ranging from 19 to 45 years. Four hundred (76\%) of the respondents had a formal education. The average monthly income was 36 USD ( $\pm 7.1 \mathrm{SD}$ ) years ranging from 20 to 100 USD. Three hundred sixty-two $(68.8 \%)$ of the respondents got $\geq 36$ USD monthly income (Table 1).

\section{Obstetric and Health Service-Related Factors}

Of the 526 respondents, more than two-thirds $(71.7 \%)$ and more than three-fourths $(86.7 \%)$ of the respondents were multigravida and ANC attended during their last pregnancy respectively. Of the 456 respondents who attended

Table I Socio-Demographic Factors of the Reproductive-Age Women in Southwest Ethiopia

\begin{tabular}{|c|c|c|c|}
\hline Variables & Categories & Frequency & Percent \\
\hline $\begin{array}{l}\text { Age group } \\
\text { (years) }\end{array}$ & $\begin{array}{l}<20 \\
21-30 \\
\geq 31\end{array}$ & $\begin{array}{l}58 \\
194 \\
274\end{array}$ & $\begin{array}{l}11 \\
36.9 \\
52.1\end{array}$ \\
\hline Religion & $\begin{array}{l}\text { Protestant } \\
\text { Orthodox } \\
\text { Muslim } \\
\text { Catholic }\end{array}$ & $\begin{array}{l}264 \\
162 \\
78 \\
22\end{array}$ & $\begin{array}{l}50.2 \\
30.8 \\
14.8 \\
4.2\end{array}$ \\
\hline $\begin{array}{l}\text { Respondents' } \\
\text { education }\end{array}$ & $\begin{array}{l}\text { Unable to read \& } \\
\text { write } \\
\text { Read and write up to } \\
\text { primary } \\
\text { Secondary and above }\end{array}$ & $\begin{array}{l}83 \\
164 \\
279\end{array}$ & $\begin{array}{l}15.8 \\
31.2 \\
53\end{array}$ \\
\hline $\begin{array}{l}\text { Husbands' } \\
\text { education }\end{array}$ & $\begin{array}{l}\text { Unable to read \& } \\
\text { write } \\
\text { Read and write up to } \\
\text { primary } \\
\text { Secondary and above }\end{array}$ & $\begin{array}{l}68 \\
175 \\
283\end{array}$ & $\begin{array}{l}12.9 \\
33.3 \\
53.8\end{array}$ \\
\hline $\begin{array}{l}\text { Monthly income } \\
\text { (USD) }\end{array}$ & $\begin{array}{l}<36 \\
\geq 36\end{array}$ & $\begin{array}{l}164 \\
362\end{array}$ & $\begin{array}{l}31.2 \\
68.8\end{array}$ \\
\hline
\end{tabular}

Abbreviation: USD, United States Dollar. 
ANC services, only 55 (12\%) of the respondents had four or more ANC visits. Of the 526 respondents interviewed, $227(43.2 \%)$ and $77(14.6 \%)$ of the respondents were knowledgeable about pregnancy danger signs and had a history of pregnancy danger signs respectively (Table 2).

\section{Factors Associated with Institutional Delivery}

The multivariable binary logistic regression (MVLR) model was employed. In MVLR model, maternal age 25-34 years $(\mathrm{AOR}=1.89,95 \%$ CI $[1.42-3.26])$ and 35 years and above $(\mathrm{AOR}=3.51,95 \%$ CI [1.52-7.85]), monthly income $\geq 36$ USD (AOR $=2.22,95 \%$ CI $[1.12-$ 4.13]), being multiparity ( $\mathrm{AOR}=1.98$, 95\% CI [1.083.62]), having $\mathrm{ANC}$ visit ( $\mathrm{AOR}=10.5$, 95\% CI [6.7628.3]), knowledge of pregnancy danger signs $(\mathrm{AOR}=5.51,95 \% \mathrm{CI}[3.46-10.2])$ and experience pregnancy danger signs (AOR=3.86, 95\% CI [2.67-7.29]) were significantly associated with institutional delivery (Table 3).

\section{Discussion}

Currently, reducing maternal morbidity and mortality is a global priority, which can be real through increasing institutional delivery service utilization. ${ }^{8,10-13}$ Considering

Table 2 Obstetric and Health Service-Related Factors of Reproductive-Age Women in Southwest Ethiopia

\begin{tabular}{|c|c|c|c|}
\hline Variables & Categories & Frequency & Percent \\
\hline \multirow[t]{2}{*}{ Gravidity $(n=526)$} & Primigravida & 149 & 28.3 \\
\hline & Multigravida & 377 & 71.7 \\
\hline \multirow{3}{*}{$\begin{array}{l}\text { Age at first pregnancy } \\
(n=526)\end{array}$} & $<20$ & 170 & 32.3 \\
\hline & $21-29$ & 300 & 57 \\
\hline & $\geq 30$ & 56 & 10.7 \\
\hline \multirow[t]{2}{*}{ Parity $(n=526)$} & $<2$ & 325 & 61.8 \\
\hline & $\geq 2$ & 201 & 38.2 \\
\hline \multirow[t]{2}{*}{ ANC visit $(n=526)$} & Yes & 456 & 86.7 \\
\hline & No & 70 & 13.3 \\
\hline \multirow{4}{*}{$\begin{array}{l}\text { Number of ANC visit } \\
(n=456)\end{array}$} & One & 214 & 46.9 \\
\hline & Two & 122 & 26.8 \\
\hline & Three & 65 & 14.3 \\
\hline & Four or above & 55 & 12 \\
\hline \multirow{2}{*}{$\begin{array}{l}\text { Knowledge on } \\
\text { pregnancy danger signs }\end{array}$} & Knowledgeable & 227 & 43.2 \\
\hline & Not knowledgeable & 299 & 56.8 \\
\hline \multirow{2}{*}{$\begin{array}{l}\text { History of pregnancy } \\
\text { danger signs }\end{array}$} & Yes & 77 & 14.6 \\
\hline & No & 449 & 85.4 \\
\hline
\end{tabular}

Abbreviation: ANC, antenatal care. the above fact, this study aimed to assess the magnitude and associated factors of institutional delivery among reproductive-age women in southwest Ethiopia. The proportion of institutional delivery was $76 \%, 95 \%$ CI $(72.4 \%-79.7 \%)$. This finding was in line with $74 \%,{ }^{15} 74.4 \%,{ }^{22} 78.3 \%$, $78.8 \%{ }^{16}$ studies conducted in Ethiopia and $78.1 \%$ in Gambia. $^{20}$ It was higher than $12.3 \%,{ }^{8} 16.9 \%{ }^{29} 24.8 \%,{ }^{5}$ $26.2 \%,{ }^{19} 31.0 \%,{ }^{9} 32.8 \%,{ }^{30} 47.3 \%,{ }^{18} 63.1 \%,{ }^{31} 64.62 \%,{ }^{14}$ $64.8 \%,{ }^{21} 71.2 \%{ }^{13}$ studies conducted in Ethiopia and $67.3 \%$ in Tanzania. ${ }^{32}$ The variation observed could be due to socio-economic; educational and sociocultural profiles. Besides, the efforts of health extension workers to provide health education for the community regarding institutional delivery may play a great variation in the increment of institutional delivery in the study area.

This study revealed that increased age of women associated with the utilization of institutional delivery. Respondents aged 25-34 years and 35 years and above were 1.9 and 3.5 times increased odds of utilizing institutional delivery than those aged $15-24$ years. This finding was consistent with studies conducted elsewhere., ${ }^{2,8,14,20,30,31}$ The reason for the increased age of mothers associated with more likely to use the service is due to the increased knowledge and good decision ability of the mothers regarding institutional delivery service.

In this study, high family income was significantly associated with institutional delivery service use. Respondents with a monthly family income $\geq 36$ USD were 2.2 times more likely to use institutional delivery service than those with a monthly family income $<36$ USD. This finding was supported by several studies conducted previously. ${ }^{1,2,19-21,29,30,32}$ This is due to the better affordability of the cost incurred from the transportation and the service itself.

In this study, parity was associated with institutional delivery use. Being multiparous women was significantly associated with the increased use of institutional delivery. Multiparous women were 2 times increased odds of having institutional delivery use than primiparous women. This finding was supported by studies done in Nepal and Bangladesh. ${ }^{1,33}$ But other studies revealed that being primiparous is statistically associated with the increased use of institutional delivery. ${ }^{9,14,20,22}$ This could be due to the understanding of the importance of institutional delivery service attained by their previous delivery.

Respondents who had ANC visits during pregnancy were 11 times more likely to use institutional delivery use than those who did not have ANC visits. Having 
Table 3 Factors Associated with Institutional Delivery Among Reproductive-Age Women in Southwest Ethiopia

\begin{tabular}{|c|c|c|c|c|c|c|}
\hline \multirow[t]{2}{*}{ Variables } & \multirow[t]{2}{*}{ Categories } & \multicolumn{2}{|c|}{$\begin{array}{l}\text { Institutional } \\
\text { Delivery }\end{array}$} & \multicolumn{2}{|c|}{ Odds Ratio $(95 \% \mathrm{Cl})$} & \multirow[t]{2}{*}{ P-value } \\
\hline & & Yes & No & COR & AOR & \\
\hline Age category & $\begin{array}{l}15-24 \\
25-34 \\
\geq 35\end{array}$ & $\begin{array}{l}83 \\
249 \\
68\end{array}$ & $\begin{array}{l}45 \\
65 \\
16\end{array}$ & $\begin{array}{l}\text { I } \\
2.08(1.32-3.27)^{* *} \\
2.30(1.20-4.43)^{* *}\end{array}$ & $\begin{array}{l}\mathrm{I} \\
1.89(1.42-3.26) \\
3.51(1.52-7.85)\end{array}$ & $\begin{array}{l}0.012 \\
0.003\end{array}$ \\
\hline Respondents' education & $\begin{array}{l}\text { Unable to read \& write } \\
\text { Read \& write up to primary } \\
\text { Secondary \& above }\end{array}$ & $\begin{array}{l}52 \\
130 \\
218\end{array}$ & $\begin{array}{l}31 \\
34 \\
61\end{array}$ & $\begin{array}{l}\text { I } \\
2.28(1.27-4.09)^{* *} \\
4.59(2.85-7.39)^{* *}\end{array}$ & $\begin{array}{l}\mathrm{I} \\
\mathrm{I} .28(0.55-3.0 \mathrm{I}) \\
\mathrm{I} .2 \mathrm{I}(0.54-2.73)\end{array}$ & $\begin{array}{l}0.569 \\
0.646\end{array}$ \\
\hline Husbands' education & $\begin{array}{l}\text { Unable to read \& write } \\
\text { Read \& write up to primary } \\
\text { Secondary \& above }\end{array}$ & $\begin{array}{l}43 \\
120 \\
243\end{array}$ & $\begin{array}{l}25 \\
55 \\
40\end{array}$ & $\begin{array}{l}\text { I } \\
1.27(0.7 \mathrm{I}-2.28)^{*} \\
3.53(\mathrm{I} .67-5.38)^{* *}\end{array}$ & $\begin{array}{l}\mathrm{I} \\
0.57(0.23-1.42) \\
0.83(0.34-2.03)\end{array}$ & $\begin{array}{l}0.226 \\
0.679\end{array}$ \\
\hline Monthly income & $\begin{array}{l}<36 \text { USD } \\
\geq 36 \text { USD }\end{array}$ & $\begin{array}{l}99 \\
301\end{array}$ & $\begin{array}{l}65 \\
61\end{array}$ & $\begin{array}{l}\text { I } \\
3.24(2.14-4.92)^{* *}\end{array}$ & $2.22(1.12-4.13)$ & 0.034 \\
\hline Parity & $\begin{array}{l}<2 \\
\geq 2\end{array}$ & $\begin{array}{l}270 \\
130\end{array}$ & $\begin{array}{l}55 \\
71\end{array}$ & $\begin{array}{l}\text { I } \\
2.28(1.37-3.77)^{* *}\end{array}$ & $1.98(1.08-3.62)$ & $<0.001$ \\
\hline ANC visit & $\begin{array}{l}\text { Yes } \\
\text { No }\end{array}$ & $\begin{array}{l}385 \\
15\end{array}$ & $\begin{array}{l}71 \\
55\end{array}$ & $\begin{array}{l}19.9(10.7-37.1)^{* *} \\
\text { I }\end{array}$ & $10.5(6.76-28.3)$ & $<0.001$ \\
\hline Knowledge on pregnancy danger signs & $\begin{array}{l}\text { Knowledgeable } \\
\text { Not knowledgeable }\end{array}$ & $\begin{array}{l}210 \\
190\end{array}$ & $\begin{array}{l}17 \\
109\end{array}$ & $\begin{array}{l}7.09(4.22-14.1)^{* *} \\
\mathrm{I}\end{array}$ & $\begin{array}{l}5.51(3.46-10.2) \\
1\end{array}$ & $<0.001$ \\
\hline History of pregnancy danger signs & $\begin{array}{l}\text { Yes } \\
\text { No }\end{array}$ & $\begin{array}{l}71 \\
329\end{array}$ & $\begin{array}{l}6 \\
120\end{array}$ & $4.32(1.83-10.2)^{* *}$ & $\begin{array}{l}3.86(2.67-7.29) \\
\mathrm{I}\end{array}$ & 0.028 \\
\hline
\end{tabular}

Notes: *Significant at $\mathrm{p}$-value $<0.25 ; * *$ Significant at $\mathrm{p}$-value $<0.05$.

Abbreviations: ANC, antenatal care; AOR, adjusted odds ratio; $\mathrm{Cl}$, confidence interval; COR, crude odds ratio; USD, United States Dollar.

ANC visits during pregnancy was very strongly associated with the increased use of institutional delivery service. This finding was supported by several studies done previously. ${ }^{2,5,8,10,13,14,19,22,29}$ The reason why ANC visit increased institutional delivery use is because of counseling of birth preparedness and place of delivery by the health care workers at ANC follow up clinic in every visit during pregnancy.

Respondents who had good knowledge of pregnancy danger signs were 5.5 times increased odds of using institutional delivery service than those who had poor knowledge of pregnancy danger signs. Having good knowledge of pregnancy danger signs was very strongly associated with institutional delivery use. This finding was consistent with studies conducted in Ethiopia and Tanzania. $^{2,10,32}$ This could be explained by those who had good knowledge of pregnancy danger signs may also have good knowledge of labor and childbirth complications. So, to avoid the related labor and childbirth complications, the chance of preferring institutional delivery is highly likely.
This study revealed a strong association between the history of pregnancy danger signs and institutional delivery use. Mothers who had a history of pregnancy danger signs were 3.9 times more likely to use institutional delivery service than those who did not have a history of pregnancy danger signs. This finding was supported by studies done in Ethiopia. ${ }^{5,34}$ This could be due to the fear of not experiencing labor and childbirth complications.

\section{Strength and Limitations}

The community-based nature of the study may be considered as strength, since asking women's in the community may gain real prevalence figure of institutional delivery use than doing in the health institution (individuals in health institution does not truly represent the community). The limitation mentioned in this study may be unable to ascertain the causal association of the dependent and independent variables (due to the chicken egg-dilemma nature of crosssectional study). Besides, recall bias may be another limitation due to the inclusion of study participants who had a history of delivery one year before this study. 


\section{Conclusion}

The utilization of institutional delivery service among mothers in the study area was good. But, more effort is needed to increase service utilization to $100 \%$. The provision of the continuous house to house health education regarding institutional delivery is an important segment of intervention that can be done through health extension workers. Besides, counseling mothers on the importance of institutional delivery by health professionals at each ANC follow up visit play paramount importance.

\section{Abbreviations}

ANC, antenatal care; AOR, adjusted odds ratio; CI, confidence interval; COR, crude odds ratio; MMR, maternal mortality ratio; USD, United States Dollar; SPSS, Statistical Package for the Social Sciences; SD, standard deviation.

\section{Data Sharing Statement}

The datasets used and/or analyzed during the current study are available from the corresponding author upon reasonable request.

\section{Ethics Approval and Consent to Participate}

Ethical approval was obtained before starting data collection from Mizan-Tepi University Institutional Review Board (MTU-IRB). All study participants were informed about the purpose of the study, their right to deny participation, anonymity, confidentiality of the information and this study was conducted in accordance with the Declaration of Helsinki. Written informed consent was also obtained before participation in the study.

\section{Consent for Publication}

Not applicable.

\section{Acknowledgments}

The author acknowledges the study participants for their valuable participation and Mizan-Aman town administration for their full collaboration and support by providing important data for this study. I would like to acknowledge data collectors and supervisors for their valuable contributions during data collection.

\section{Funding}

There is no funding to report.

\section{Disclosure}

The author declares no conflict of interests.

\section{References}

1. Tamang JP, Mcneil R, Tongkumchum P. Factors associated with non-institutional delivery among pregnant women in Nepal. Asian Soc Sci. 2019;15(7):43-48. doi:10.5539/ass.v15n7p43

2. Tadele N, Lamaro T. Utilization of institutional delivery service and associated factors in Bench Maji zone, Southwest Ethiopia: community based, cross sectional study. BMC Health Serv Res. 2017;17:101. doi:10.1186/s12913-017-2057-y

3. WHO, UNICEF WBG. Trends in maternal mortality: 1990 to 2015. 2015;31:1-55.

4. WHO, UNICEF and U. Trends in Maternal Mortality: 1999-2013. Geneva: Switzerland; 2014.

5. Muluwas Amentie MA, Abdulahi M. Utilization of institutional delivery care services and influencing factors among women of child bearing age in Assosa District, Benishangul Gumuz Regional State, West Ethiopia. Glob J Med Res. 2016;16:3.

6. Abdella A. Maternal mortality trend in Ethiopia. Ethiop J Heal Dev. 2010;24:115-122.

7. UNFPA. Trends in maternal health in Ethiopia: challenges in achieving the MDG for maternal mortality. In-depth Analysis of the EDHS 2000-2011. 2012.

8. Amano A, Gebeyehu A, Birhanu Z. Institutional delivery service utilization in Munisa Woreda, South East Ethiopia: a community based cross-sectional study. BMC Pregnancy Childbirth. 2012;12:105. doi:10.1186/1471-2393-12-105

9. Fekadu A, Yitayal M, Alemayehu GA, et al. Frequent antenatal care visits increase institutional delivery at dabat health and demographic surveillance system site, Northwest Ethiopia. $J$ Pregnancy. 2019;2019.

10. Demilew YM, Gebregergs GB, Negusie AA. Factors associated with institutional delivery in Dangila district, North West Ethiopia: a cross-sectional study. Afri Heal Sci. 2016;16(1):10-17. doi:10.4314/ ahs.v16i1.2

11. Hossain FHM. Determinant of choice of delivery care in some urban slum of Daka city. Pakistan J Soc Sci. 2005;3(3):9-19.

12. Centeral Statistical Agency. Ethiopia Demographic and Health Survey: Preliminary Report. Maryland, USA: MEASURE DHS, ICF Macro Calverton; 2011.

13. Bayu H, Fisseha G, Mulat GY A. Missed opportunities for institutional delivery and associated factors among urban resident pregnant women in South Tigray Zone, Ethiopia: a community-based follow-up study. Glob Health Action. 2015;8(1):28082. doi:10.3402/ gha.v8.28082

14. Yegezu RT, Kitila SB. Assessment of factors affecting choice of delivery place among pregnant women in jimma zone, south west ethiopia: cross sectional study. J Women's Heal Care. 2014;4(1):1-4.

15. Assefa M, Fite RO, Ayanos Taye TB. Institutional delivery service use and associated factors among women who delivered during the last 2 years in Dallocha town, SNNPR, Ethiopia. Nurs Open. 2020;7:186-194.

16. Abeje G, Azage M, Setegn T. Factors associated with Institutional delivery service utilization among mothers in Bahir Dar City administration, Amhara region: a community based cross sectional study. Reprod Health. 2014;11:22. doi:10.1186/1742-4755-11-22

17. Tadele T, Tamiso A, Tadele T. Factors associated with institutional delivery in Boricha District of Sidama Zone, Southern Ethiopia. Int J Public Heal Sci. 2015;3(4):224-230.

18. Nigatu AM, Gelaye KA. Factors associated with the preference of institutional delivery after antenatal care attendance in Northwest Ethiopia. BMC Health Serv Res. 2019;6:810. doi:10.1186/s12913019-4636-6 
19. Ketemaw A, Tareke M, Dellie E, et al. Factors associated with institutional delivery in Ethiopia: a cross sectional study. $B M C$ Health Serv Res. 2020;7:266. doi:10.1186/s12913-020-05096-7

20. Barrow A, Jobe A, Onoh VI, Maduako KT. Prevalence and factors associated with institutional-based delivery in the Gambia: further analysis of population-based cross- sectional data. Afr $J$ Reprod Health. 2020;24(2):176-186.

21. Wodaynew T, Fekecha B, Abdisa B. Magnitude of home delivery and associated factors among antenatal care booked mothers in Delanta District, South Wollo Zone, North East Ethiopia: a cross-sectional study, March 2018. Int J Womens Health Wellness. 2018;4(2):1-11.

22. Siraneh Y, Wondimnew F. Institutional delivery services utilization and associated factors among mothers who gave birth in the last one year in Jimma Town, Southwest Ethiopia. J Complement Med Alt Healthc. 2018;8:3.

23. Shahabuddin ASM, De BV, Adhikari R, Delamou A, Bardaj A, Delvaux T. Determinants of institutional delivery among young married women in Nepal: evidence from the Nepal Demographic and Health Survey, 2011. BMJ Open. 2017;7:e012446. doi:10.1136/bmjopen-2016-012446

24. Crowe S, Utley M, Costello APC. How many births in sub-Saharan Africa and South Asia will not be attended by a skilled birth attendant between 2011 and 2015. BMC Pregnancy Childbirth. 2012;12(1):4. doi:10.1186/1471-2393-12-4

25. Habte F, Demissie M. Magnitude and factors associated with institutional delivery service utilization among childbearing mothers in Cheha district, Gurage zone, SNNPR, Ethiopia: a community based cross sectional study. BMC Pregnancy Childbirth. 2015;15:299. doi:10.1186/s12884-015-0716-8
26. Mehari AM. Levels and determinants of use of institutional delivery care services among women of childbearing age in Ethiopia: analysis of EDHS 2000 and 2005 Data. 2013.

27. Bililign N, Mulatu T. Knowledge of obstetric danger signs and associated factors among reproductive age women in Raya Kobo district of Ethiopia: a community based cross-sectional study. BMC Pregnancy Childbirth. 2017;17(1):70. doi:10.1186/s12884-017-1253-4

28. Dutta DC. Text Book of Obstetrics. 6th ed ed. Calcutta: New Central Book Agency (P) Ltd; 2004:121-124.

29. Brhanie TW, Anteneh HA. Level of institutional delivery service utilization and associated factors among women who gave birth in the last one year in Gonji Kollela District, Amhara Region, Ethiopia: cross-sectional study. Prim Heal Care. 2016;6:3.

30. Chernet AG, Dumga KT, Cherie KT. Home delivery practices and associated factors in Ethiopia. $J$ Reprod Infertility. 2019;20 (2):102-108.

31. Jinka SM, Wodajo LT, Agero G. Predictors of institutional delivery service utilization, among women of reproductive age group in Dima District, Agnua zone, Gambella, Ethiopia. Med Pract Rev. 2018;9 (2):8-18. doi:10.5897/MPR2018.0135

32. Bishanga DR, Drake M, Kim Y, et al. Factors associated with institutional delivery: findings from a cross-sectional study in Mara and Kagera regions in Tanzania. PLoS One. 2018;13(12):e0209672. doi:10.1371/journal.pone.0209672

33. Das. AC, Biswas MK. Factors associated with institutional delivery among the rural women in Bangladesh. Mediscope. 2016;3(2):18-25. doi:10.3329/mediscope.v3i2.30163

34. Kebede A, Hassen K, Teklehaymanot AN. Factors associated with institutional delivery service utilization in Ethiopia. Int $J$ Women's Heal. 2016;8:463-475. doi:10.2147/IJWH.S109498
International Journal of Women's Health

\section{Publish your work in this journal}

The International Journal of Women's Health is an international, peerreviewed open-access journal publishing original research, reports, editorials, reviews and commentaries on all aspects of women's healthcare including gynecology, obstetrics, and breast cancer. The manuscript management system is completely online and includes a very quick and fair peer-review system, which is all easy to use. Visit http://www.dovepress.com/testimonials.php to read real quotes from published authors. 